\title{
Streptomyces jietaisiensis sp. nov., isolated from soil in northern China
}

\author{
Liang He, ${ }^{1}$ Wei Li, ${ }^{1}$ Ying Huang, ${ }^{1}$ Liming Wang, ${ }^{1}$ Zhiheng Liu, ${ }^{1}$ \\ Benjamin Lanoot, ${ }^{2}$ Marc Vancanneyt ${ }^{2}$ and Jean Swings ${ }^{2}$ \\ ${ }^{1}$ State Key Laboratory of Microbial Resources, Institute of Microbiology, Chinese Academy of \\ Sciences, Beijing 100080, People's Republic of China \\ ${ }^{2}$ BCCM/LMG Bacteria Collection, Department of Biochemistry, Physiology and Microbiology, \\ Universiteit Gent, K. L. Ledeganckstraat 35, B-9000 Gent, Belgium
}

Correspondence

Ying Huang

huangy@im.ac.cn

\begin{abstract}
An actinomycete, strain $\mathrm{FXJ}_{4} \mathrm{6}^{\top}$, was isolated from cypress forest soil in northern China and shown to have chemotaxonomic and morphological properties consistent with streptomycetes. It developed greyish aerial mycelium and pinkish-brown substrate mycelium on oatmeal agar. Phylogenetic analyses based on an almost complete 16S rRNA gene sequence of the strain and on the 120 nucleotide variable $\gamma$-region of this molecule showed that it formed a distinct (but closely associated) line with Streptomyces griseoaurantiacus DSM $40430^{\top}$ in Streptomyces trees. However, the DNA-DNA relatedness between the two strains was only $48 \cdot 8 \%$. A number of phenotypic properties also readily distinguished the isolate from $S$. griseoaurantiacus and related Streptomyces species with validly published names. It is proposed, therefore, that this organism be classified as a novel species of the genus Streptomyces, for which the name Streptomyces jietaisiensis sp. nov. is proposed. The type strain is FXJ46 ${ }^{\top}$ $\left(=\right.$ AS $\left.4.1859^{\top}=\mathrm{JCM} 12279^{\top}\right)$.
\end{abstract}

In the last decade, the taxonomy of the genus Streptomyces has undergone much improvement, in part due to increased interest in the identification of these organisms, particularly those from the soil environment. The use of molecular taxonomic methods such as 16S rRNA gene sequencing has done much to aid the classification of this complex group and the recognition of novel species (Kim \& Goodfellow, 2002; S. B. Kim et al., 1998, 2004; Al-Tai et al., 1999; B. Kim et al., 2000; Li et al., 2002; Saintpierre et al., 2003). However, due to the large number of species, the complete $16 \mathrm{~S}$ rRNA gene sequences have not been determined for many type strains of this genus; incomplete sequence data may result in misclassification (Kataoka et al., 1997; Anderson \& Wellington, 2001). In this study, therefore, the partial sequence (120 nucleotides ) covering the variable $\gamma$-region of the 16S rRNA gene was also analysed phylogenetically to classify strain FXJ46 ${ }^{\mathrm{T}}$. While phylogenetic data showed that it was closely related to $S$. griseoaurantiacus DSM $40430^{\mathrm{T}}$, polyphasic studies based on a judicious

Published online ahead of print on 6 May 2005 as DOI 10.1099/ ijs.0.63460-0.

The GenBank/EMBL/DDBJ accession numbers for the 16S rRNA gene sequences of strains $F X J 46^{\top}$ and $S$. griseoaurantiacus DSM $40430^{\top}$ are $A Y 314783$ and $A Y 450561$, respectively.

A micrograph showing aerial hyphae with rectiflexibiles spore chains and a neighbour-joining tree based on the 120 nt $\gamma$-region are available as supplementary material in IJSEM Online. combination of genotypic and phenotypic features revealed a novel species of Streptomyces.

Strain FXJ46 ${ }^{\mathrm{T}}$ was isolated on a yeast extract-starch agar (Emerson, 1958) plate supplemented with $50 \mu \mathrm{g}$ cycloheximide $\mathrm{ml}^{-1}$, which had been seeded with a soil sample suspension and incubated for 14 days at $28^{\circ} \mathrm{C}$. The soil sample was collected from a cypress forest, at Jietaisi, Beijing, China. The isolate was maintained on yeast extractstarch slopes at $4{ }^{\circ} \mathrm{C}$ and as glycerol suspensions $(20 \%$, $\mathrm{v} / \mathrm{v})$ at $-20{ }^{\circ} \mathrm{C}$. Biomass for the chemotaxonomic and molecular systematic studies was prepared as described previously (Li et al., 2002).

The morphological characteristics of strain $\mathrm{FXJ}^{4} 6^{\mathrm{T}}$ were examined by light and scanning electron microscopy of 14day cultures grown on oatmeal agar and inorganic saltsstarch agar (ISP medium 4). The coverslip technique (Zhou et al., 1998; Kawato \& Shinobu, 1959) was used to observe the hyphae and spore-chain characters by light microscope. Spore-chain morphology and spore-surface ornamentation were studied by examining gold-coated dehydrated specimens with a model FEI QUANTA electron microscope. The cultural features were observed on a number of standard media (Table 1) after 14 days incubation at $28^{\circ} \mathrm{C}$. The test strain was examined for a range of biochemical and physiological properties as described by Williams et al. (1983) and Kämpfer et al. (1991). 
Table 1. Comparison of cultural characteristics of strain $\mathrm{FXJ} 46^{\top}$ and Streptomyces griseoaurantiacus $\mathrm{DSM}^{40430^{\top}}$

No pigments were formed on the listed agars.

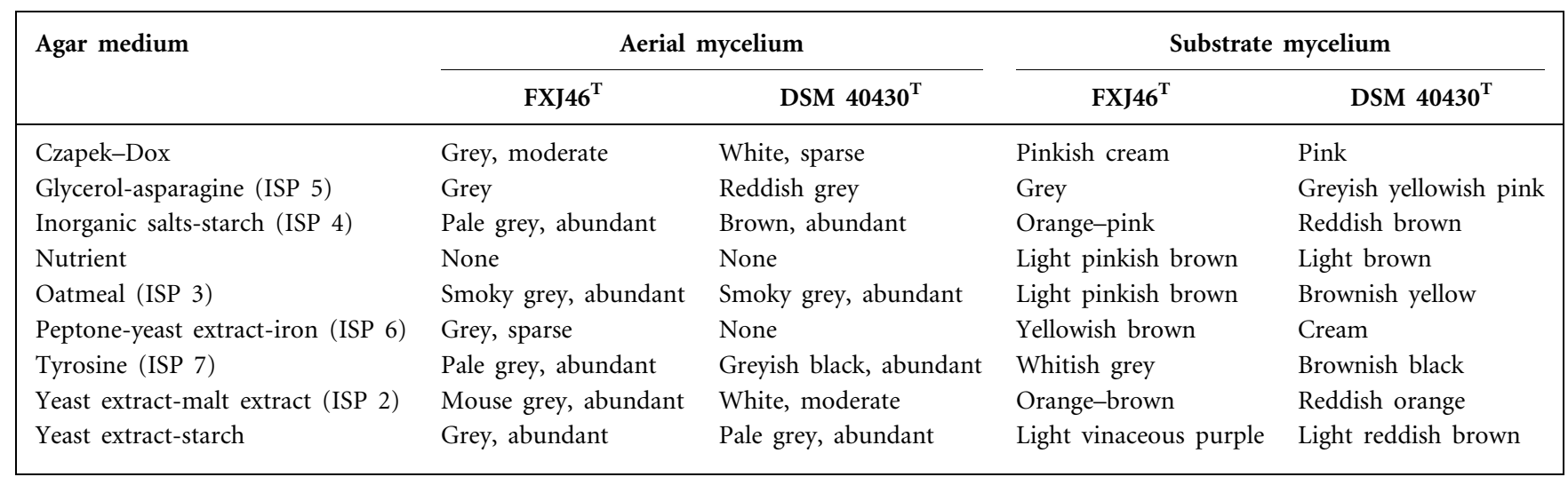

The isomers of diaminopimelic acid and whole-organism sugars were analysed following the procedures developed by Hasegawa et al. (1983) and Lechevalier \& Lechevalier (1980). Menaquinones were extracted and purified according to Collins (1985) and analysed by HPLC. Polar lipids were examined and identified using the method of Minnikin et al. (1984). The fatty acids were extracted, methylated and analysed by GC using the standard Sherlock MIDI (Microbial Identification) system (Sasser, 1990; Kämpfer \& Kroppenstedt, 1996). The G $+C$ content of the DNA of the test strain was determined using the thermal denaturation method (Marmur \& Doty, 1962) with Escherichia coli AS 1.365 as a control.

Genomic DNA preparation and PCR amplification of the $16 \mathrm{~S}$ rRNA gene of strain FXJ46 ${ }^{\mathrm{T}}$ were carried out using the procedure of Chun \& Goodfellow (1995). The PCR products were sequenced using the method of Huang et al. (2001). CLUSTAL X version 1.8 (Thompson et al., 1997) was used for multiple alignment with available almost-complete sequences of type strains of the family Streptomycetaceae and then with corresponding sequences of representative Streptomyces species; in each case, the reference sequences were retrieved from the DDBJ/EMBL/GenBank databases. The least-squares (Fitch \& Margoliash, 1967), maximumlikelihood (Felsenstein, 1981), maximum-parsimony (Kluge \& Farris, 1969) and neighbour-joining (Saitou \& Nei, 1987) algorithms from the PHYLIP package version $3.5 \mathrm{c}$ (Felsenstein, 1993) were used to infer the phylogenetic trees. Evolutionary distance matrices were generated as described by Kimura (1980). Tree topologies were evaluated by bootstrap analyses (Felsenstein, 1985) based on 1000 resamplings. The partial sequence covering the variable $\gamma$-region (120 nt, positions 158-277) of the 16S rRNA gene sequence of strain FXJ46 ${ }^{\mathrm{T}}$ was also compared with corresponding nucleotide sequences of 485 Streptomyces type strains retrieved from GenBank. A phylogenetic tree based on these partial sequences was constructed using the neighbourjoining algorithm (Saitou \& Nei, 1987).
Levels of DNA-DNA relatedness between strain FXJ $46^{\mathrm{T}}$ and S. griseoaurantiacus DSM $40430^{\mathrm{T}}$ were determined according to the fluorometric micro-well method (Ezaki et al., 1989), with the modification that detection of the DNA hybridization rate was tested by the addition of streptavidinconjugate alkaline phosphatase acting on the substrate 4methylumbelliferyl phosphate (Christensen et al., 2000). Fluorescence intensities were measured using a Fluostar Optima microplate reader (BMG LABTECH) at a wavelength of $360 \mathrm{~nm}$ for excitation and $460 \mathrm{~nm}$ for emission. The DNA hybridization rate was calculated from quadruplicated hybridization experiments and expressed as a mean of the corresponding reciprocal values.

The organism exhibited a range of chemotaxonomic and phenotypic properties typical of members of the genus Streptomyces. It formed an extensively branched substrate mycelium, aerial hyphae which carried smooth-surfaced spores in rectiflexibiles spore chains (see Supplementary Fig. S1 available in IJSEM Online) and a greyish aerial spore mass on several standard media (Table 1). It contained LL-diaminopimelic acid in whole-organism hydrolysates, hexa-, octa- and a minor amount of tetrahydrogenated menaquinones with nine isoprene units $\left[\mathrm{MK}-9\left(\mathrm{H}_{6}, \mathrm{H}_{8}\right.\right.$ and $\left.\mathrm{H}_{4}\right)$ ] as isoprenologues, and diphosphatidylglycerol, phosphatidylethanolamine, phosphatidylinositol and phosphatidylinositol mannosides as major polar lipids (phospholipid type II sensu Lechevalier et al., 1977). The fatty acid profile was composed mainly of saturated straight-chain and iso- and anteiso-branched-chain fatty acids (fatty acid type 2c sensu Kroppenstedt, 1985).

An almost complete 16S rRNA gene sequence (1426 nt) was determined for the organism. Primary sequence analysis with sequences of representatives of the family Streptomycetaceae confirmed that the unknown isolate was closely related to species of the genus Streptomyces. The highest $16 \mathrm{~S}$ rRNA gene sequence similarity value was found with Streptomyces nogalater JCM $4799^{\mathrm{T}}(97 \cdot 5 \%)$. However, in the phylogenetic tree based on the $120 \mathrm{nt} \gamma$-region, the strain 
showed a very close affinity with S. griseoaurantiacus, supported by a $97 \%$ bootstrap level, and was loosely related to other species (see Supplementary Fig. S2). The almostcomplete $16 \mathrm{~S}$ rRNA gene sequence (1458 nt) of S. griseoaurantiacus DSM $40430^{\mathrm{T}}$ was therefore also determined in this study, and added to the $16 \mathrm{~S}$ rRNA gene analysis. It is clear from Fig. 1 that strain FXJ46 ${ }^{\mathrm{T}}$ consistently formed a distinct phyletic line with S. griseoaurantiacus DSM $40430^{\mathrm{T}}$, suported by all four tree-making algorithms and by high bootstrap values. A $100 \%$ bootstrap value with the neighbour-joining method was indicated. The divergence of the 16S rRNA gene sequences between the two strains was $0 \cdot 2 \%$ (3 nt differences at 1421 sites). The isolate also showed moderately low sequence divergence from other Streptomyces type strains, namely S. nogalater JCM $4799^{\mathrm{T}}$ $(2 \cdot 2 \%)$, Streptomyces ambofaciens ATCC $23877^{\mathrm{T}}(2 \cdot 2 \%)$, Streptomyces rutgersensis subsp. rutgersensis DSM $40077^{\mathrm{T}}$ $(2 \cdot 3 \%)$, Streptomyces intermedius DSM $40372^{\mathrm{T}}(2 \cdot 3 \%)$, Streptomyces paradoxus DSM $43350^{\mathrm{T}}(2 \cdot 3 \%)$, Streptomyces gougerotii DSM $40324^{\mathrm{T}}(2 \cdot 4 \%)$, Streptomyces violaceolatus DSM $40438^{\mathrm{T}}(2 \cdot 4 \%)$, Streptomyces collinus DSM $40129^{\mathrm{T}}$ $(2 \cdot 5 \%)$ and Streptomyces eurythermus DSM $40014^{\mathrm{T}}(2 \cdot 6 \%)$, respectively. Therefore, well-selected phenotypic traits and DNA-DNA pairing data are needed (Kim et al., 1998; Labeda, 1988) to clarify the finer relationships between the isolate and the phylogenetically close species.

The DNA-DNA relatedness between strain $\mathrm{FXJ}_{4}{ }^{\mathrm{T}}$ and S. griseoaurantiacus DSM $40430^{\mathrm{T}}$ was $48 \cdot 8 \%$, which is well below the $70 \%$ cut-off point for recognition of genomic species (Wayne et al., 1987), thus suggesting that the test strain should be considered as a separate species.
Furthermore, the strain was distinguished from S. griseoaurantiacus DSM $40430^{\mathrm{T}}$ by cultural characteristics on a number of standard media (Table 1), by spore-chain characters and by a set of physiological features (Table 2). The test strain can also be distinguished from all of the other phylogenetically close relatives using a combination of phenotypic properties (Table 2).

Based on the genotypic and phenotypic evidence, strain FXJ $46^{\mathrm{T}}$ warrants classification as the type strain of a novel species of the genus Streptomyces, for which the name Streptomyces jietaisiensis sp. nov. is proposed.

\section{Description of Streptomyces jietaisiensis sp. nov.}

Streptomyces jietaisiensis (jie.tai.si.en'sis. N.L. masc. adj. jietaisiensis pertaining to Jietaisi, a place in a suburb of Beijing, where the type strain was isolated).

The organism is aerobic, Gram-positive and mesophilic. The characteristics of aerial and substrate mycelium on various solid media is given in Table 1 . Spore chains with 10 to 20 cylindrical spores are rectiflexibiles. The spore surface is smooth. Diffusible pigments are not produced, nor are melanin pigments formed on peptone-yeast extract-iron or tyrosine agars. Growth occurs between 10 and $40{ }^{\circ} \mathrm{C}$, and between $\mathrm{pH} 5 \cdot 0$ and $10 \cdot 0$, but not at $\mathrm{pH} 4.0$ or 11.0 or in the presence of streptomycin $\left(10 \mu \mathrm{g} \mathrm{ml}^{-1}\right)$ or novobiocin $\left(5 \mu \mathrm{g} \mathrm{ml}^{-1}\right)$. Adonitol, D-cellobiose, dextrin, D-galactose, D-glucose, inulin, glycogen, D-maltose, D-mannitol, D-mannose, D-melezitose, salicin, D-trehalose, D-xylose, (all at $1 \%, \mathrm{w} / \mathrm{v}), \mathrm{L}$-alanine, L-arginine, L-aspartic acid, L-cysteine, L-glutamic acid, L-histidine, L-isoleucine,

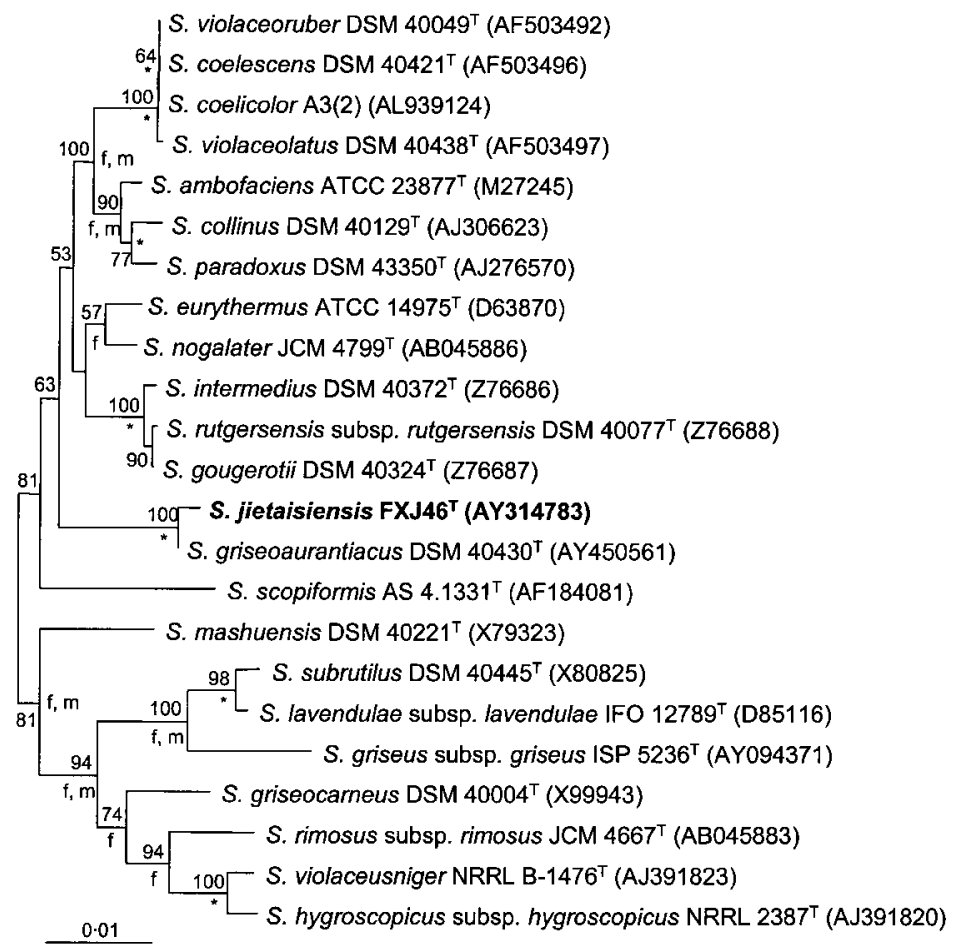

Fig. 1. Unrooted neighbour-joining tree (Saitou \& Nei, 1987) based on almostcomplete 16S rRNA gene sequences showing the phylogenetic relationships between Streptomyces jietaisiensis $\mathrm{FXJ} 46^{\top}$ and related Streptomyces species. Asterisks indicate branches that were recovered using least-squares (Fitch \& Margoliash, 1967), maximum-likelihood (Felsenstein, 1981) and maximum-parsimony (Kluge \& Farris, 1969) algorithms.; $f$ and $m$ respectively indicate branches that were also formed when the least-squares and maximum-likelihood treemaking algorithms were used. Bootstrap values $(>50 \%)$ based on 1000 replications are shown at nodes of the tree. Bar, 0.01 substitutions per nucleotide position. 
Table 2. Phenotypic characteristics of strain $\mathrm{FXJ} 46^{\top}$ and related Streptomyces species

Strains: 1, strain FXJ46 ${ }^{\mathrm{T}}$; 2, S. ambofaciens ATCC $23877^{\mathrm{T}} ; 3$, S. collinus DSM $40129^{\mathrm{T}} ; 4$, S. eurythermus DSM 40014 ${ }^{\mathrm{T}}$; 5, S. gougerotii

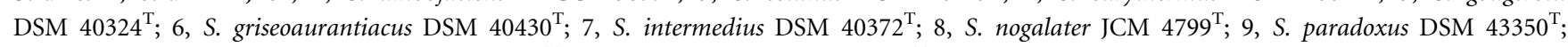

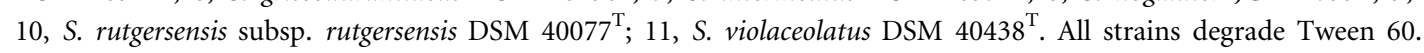

\begin{tabular}{|c|c|c|c|c|c|c|c|c|c|c|c|}
\hline Characteristic & 1 & 2 & 3 & 4 & 5 & 6 & 7 & 8 & 9 & 10 & 11 \\
\hline $\begin{array}{l}\text { Aerial spore mass on } \\
\text { oatmeal agar }\end{array}$ & $\begin{array}{l}\text { Smoky } \\
\text { grey }\end{array}$ & Light grey & $\begin{array}{l}\text { Greyish } \\
\text { white }\end{array}$ & Grey & Inadequate & $\begin{array}{l}\text { Smoky } \\
\text { grey }\end{array}$ & $\begin{array}{c}\text { Pale greyish } \\
\text { yellow or } \\
\text { inadequate }\end{array}$ & $\begin{array}{l}\text { Brownish } \\
\text { grey }\end{array}$ & $\begin{array}{l}\text { Greyish } \\
\text { white }\end{array}$ & $\begin{array}{l}\text { Greyish } \\
\text { yellow }\end{array}$ & $\begin{array}{c}\text { Brownish } \\
\text { grey }\end{array}$ \\
\hline $\begin{array}{l}\text { Spore-chain } \\
\text { morphology }\end{array}$ & RF & SP & SP to RA & RA to SP & RF & SP & $\mathrm{RF}$ & RF to RA & RA & $\mathrm{RF}$ & SP \\
\hline Spore surface & Smooth & $\begin{array}{l}\text { Smooth } \\
\text { to warty }\end{array}$ & Smooth & Smooth & Smooth & Smooth & Smooth & Smooth & Smooth & Smooth & Smooth \\
\hline Melanin production & - & - & + & - & - & - & - & - & + & - & - \\
\hline $\begin{array}{l}\text { Production of } \\
\text { diffusible pigments }\end{array}$ & - & $\begin{array}{l}\text { Yellow } \\
\text { or - }\end{array}$ & - & - & - & - & $\begin{array}{l}\text { Yellow } \\
\text { or - }\end{array}$ & $\begin{array}{l}\text { Orange- } \\
\text { yellow } \\
\text { to red }\end{array}$ & - & - & $\begin{array}{l}\text { Violet } \\
\text { or red }\end{array}$ \\
\hline \multicolumn{12}{|l|}{ Degradation of: } \\
\hline Adenine & + & + & - & + & + & - & - & + & - & + & + \\
\hline Arbutin & + & + & - & - & - & + & - & - & + & + & + \\
\hline Elastin & - & - & - & + & + & - & + & + & + & + & - \\
\hline Guanine & - & - & - & - & + & - & + & + & + & + & - \\
\hline Hypoxanthine & - & + & + & + & + & - & + & + & + & + & + \\
\hline Tween 20 & + & - & + & + & + & + & + & + & - & + & + \\
\hline Tween 40 & + & + & + & + & + & + & + & + & - & + & + \\
\hline Tween 80 & + & - & + & + & - & + & - & - & - & + & + \\
\hline Xanthine & - & + & - & + & + & - & - & + & + & + & - \\
\hline Xylan & + & - & - & + & - & + & + & + & - & - & - \\
\hline \multicolumn{12}{|l|}{$\begin{array}{l}\text { Growth on sole carbon } \\
\text { sources }(1 \cdot 0 \%, \mathrm{w} / \mathrm{v}) \text { : }\end{array}$} \\
\hline L-Arabinose & + & + & + & + & + & + & + & + & + & + & - \\
\hline $\begin{array}{l}\text { Methyl } \alpha \text {-D- } \\
\text { glucopyranoside }\end{array}$ & + & + & + & - & + & - & + & - & + & + & + \\
\hline Inositol & + & + & + & - & + & + & - & + & + & + & - \\
\hline D-Inulin & - & + & - & - & - & - & - & - & + & - & - \\
\hline D-Lactose & + & + & - & + & + & + & - & + & + & + & - \\
\hline D-Raffinose & + & + & + & + & - & + & - & + & + & - & - \\
\hline L-Rhamnose & + & + & - & - & - & + & - & - & + & + & - \\
\hline D-Ribose & + & + & + & + & + & + & + & + & + & + & - \\
\hline D-Sorbitol & + & - & + & + & + & - & - & + & - & + & + \\
\hline D-Sorbose & - & - & + & - & + & - & - & - & - & - & + \\
\hline D-Sucrose & - & + & + & + & + & + & + & + & + & - & - \\
\hline $\begin{array}{l}\text { Sodium acetate } \\
(0 \cdot 1 \%)\end{array}$ & + & + & - & + & - & + & + & + & - & + & - \\
\hline $\begin{array}{l}\text { Sodium citrate } \\
(0 \cdot 1 \%)\end{array}$ & + & + & - & + & + & + & - & + & - & + & - \\
\hline $\begin{array}{l}\text { Sodium malonate } \\
(0 \cdot 1 \%)\end{array}$ & - & + & - & + & + & + & + & + & + & + & - \\
\hline \multicolumn{12}{|l|}{ Growth on: } \\
\hline $5 \% \mathrm{NaCl}$ & + & + & + & + & + & - & + & + & + & + & + \\
\hline $7 \% \mathrm{NaCl}$ & + & + & - & + & - & - & + & + & - & + & - \\
\hline $10 \% \mathrm{NaCl}$ & - & - & - & - & - & - & - & - & - & + & - \\
\hline $0 \cdot 1 \%$ Phenol & - & + & - & + & - & - & + & + & - & - & - \\
\hline $0 \cdot 01 \% \mathrm{NaN}_{3}$ & + & - & - & + & + & + & + & - & + & + & - \\
\hline Growth at $45^{\circ} \mathrm{C}$ & - & + & + & + & - & - & - & + & + & - & - \\
\hline
\end{tabular}

${ }^{*} \mathrm{RA}$, Retinaculiaperti; RF, rectiflexibiles; SP, spiral. 
L-phenylalanine, sodium oxalate, sodium pyruvate, Lthreonine and L-valine (all at $0 \cdot 1 \%, \mathrm{w} / \mathrm{v}$ ) are used as sole carbon sources for energy and growth, but not glycerol, glycine, xylitol (all at $1 \%, w / v)$ or DL-aminobutyric acid (at $0 \cdot 1 \%, \mathrm{w} / \mathrm{v})$. L-alanine, L-arginine, L-aspartic acid, L-glutamic acid and L-phenylalanine (all at $0 \cdot 1 \%, \mathrm{w} / \mathrm{v}$ ) are metabolized as sole carbon and nitrogen sources, but not $\mathrm{L}$-isoleucine (at $0 \cdot 1 \%, \mathrm{w} / \mathrm{v})$. Cell wall type I, phospholipid type II and menaquinone MK-9 $\left(\mathrm{H}_{6}, \mathrm{H}_{8}\right.$ and $\left.\mathrm{H}_{4}\right)$. The fatty acid profile is composed of ai- $\mathrm{C}_{15: 0}(35 \cdot 7 \%)$, ai- $\mathrm{C}_{17: 0}(18 \cdot 9 \%)$, i- $\mathrm{C}_{16: 0}(14 \cdot 8 \%)$, ai- $\mathrm{C}_{17: 1} \omega 9 c(8 \cdot 1 \%)$, $\mathrm{C}_{16: 0}(6 \cdot 2 \%), \mathrm{i}-\mathrm{C}_{16: 1}(4 \cdot 5 \%), \mathrm{i}-\mathrm{C}_{15: 0}(4 \cdot 3 \%), \mathrm{C}_{16: 1} \omega 7 \mathrm{c}$ $(2 \cdot 33 \%), \mathrm{i}-\mathrm{C}_{17: 1} \omega 9 c(1 \cdot 8 \%), \mathrm{i}-\mathrm{C}_{17: 0}(1 \cdot 7 \%)$ and $\mathrm{i}-\mathrm{C}_{14: 0}$ $(1 \cdot 7 \%)$. The $\mathrm{G}+\mathrm{C}$ content of the DNA is $72 \cdot 3 \mathrm{~mol} \%$. Additional characteristics are listed in Table 2.

The type strain is FXJ46 ${ }^{\mathrm{T}}\left(=\mathrm{AS} 4.1859^{\mathrm{T}}=\mathrm{JCM} 12279^{\mathrm{T}}\right)$, isolated from cypress forest soil collected at Jietaisi, Beijing, China.

\section{Acknowledgements}

This work was supported by the Natural Science Foundation of China (NSFC, grant number 30370002) and by the Federal PPS Science Policy of Belgium (grant BL/02/C10). The authors are grateful to Professor R. M. Kroppenstedt (DSMZ, Germany) and Dr T. Kudo (JCM, Japan) for providing type cultures and to Mrs Yamei Zhang for her assistance in strain isolation.

\section{References}

Al-Tai, A., Kim, B., Kim, S. B., Manfio, G. P. \& Goodfellow, M. (1999). Streptomyces malaysiensis sp. nov., a new streptomycete species with rugose, ornamented spores. Int J Syst Bacteriol 49, 1395-1402.

Anderson, A. S. \& Wellington, E. M. H. (2001). The taxonomy of Streptomyces and related genera. Int J Syst Evol Microbiol 51, 797-814.

Christensen, H., Angen, Ø., Mutters, R., Olsen, J. E. \& Bisgaard, M. (2000). DNA-DNA hybridization determined in micro-wells using covalent attachment of DNA. Int J Syst Evol Microbiol 50, 1095-1102.

Chun, J. \& Goodfellow, M. (1995). A phylogenetic analysis of the genus Nocardia with $16 \mathrm{~S}$ rRNA gene sequences. Int J Syst Bacteriol 45, 240-245.

Collins, M. D. (1985). Isoprenoid quinone analysis in classification and identification. In Chemical Methods in Bacterial Systematics, pp. 267-287. Edited by M. Goodfellow \& D. E. Minnikin. London: Academic Press.

Emerson, R. (1958). Mycological organization. Mycologia 50, 589-621.

Ezaki, T., Hashimoto, Y. \& Yabuuchi, E. (1989). Fluorometric deoxyribonucleic acid-deoxyribonucleic acid hybridization in microdilution wells as an alternative to membrane filter hybridization in which radioisotopes are used to determine genetic relatedness among bacterial strains. Int J Syst Bacteriol 39, 224-229.

Felsenstein, J. (1981). Evolutionary trees from DNA sequences: a maximum likelihood approach. J Mol Evol 17, 368-376.

Felsenstein, J. (1985). Confidence limits on phylogenies: an approach using the bootstrap. Evolution 39, 783-791.
Felsenstein, J. (1993). PHYLIP - Phylogenetic Inference Package, version 3.5c. Distributed by the author. Department of Genome Sciences, University of Washington, Seattle, USA.

Fitch, W. M. \& Margoliash, E. (1967). Construction of phylogenetic trees: a method based on mutation distances as estimated from cytochrome $c$ sequences is of general applicability. Science 155, 279-284.

Hasegawa, T., Takizawa, M. \& Tanida, S. (1983). A rapid analysis for chemical grouping of aerobic actinomycetes. J Gen Appl Microbiol 29, 319-322.

Huang, Y., Qi, W., Lu, Z., Liu, Z. \& Goodfellow, M. (2001). Amycolatopsis rubida sp. nov., a new Amycolatopsis species from soil. Int J Syst Evol Microbiol 51, 1093-1097.

Kämpfer, P. \& Kroppenstedt, R. M. (1996). Numerical analysis of fatty acid patterns of coryneform bacteria and related taxa. Can J Microbiol 42, 989-1005.

Kämpfer, P., Kroppenstedt, R. M. \& Dott, W. (1991). A numerical classification of the genera Steptomyces and Streptoverticillium using miniaturized physiological tests. J Gen Microbiol 137, 1831-1891.

Kataoka, M., Ueda, K., Kudo, T., Seki, T. \& Yoshida, T. (1997). Application of the variable region in $16 \mathrm{~S}$ rDNA to create an index for rapid species identification in the genus Streptomyces. FEMS Microbiol Lett 151, 249-255.

Kawato, M. \& Shinobu, R. (1959). On Streptomyces herbaricolor sp. nov., supplement: a single technique for microscopical observation. Mem Osaka Univ Lib Arts Educ B Nat Sci 8, 114-119.

Kim, S. B. \& Goodfellow, M. (2002). Streptomyces avermitilis sp. nov., nom. rev., a taxonomic home for the avermectin-producing streptomycetes. Int J Syst Evol Microbiol 52, 2011-2014.

Kim, S. B., Falconer, C., Williams, E. \& Goodfellow, M. (1998). Streptomyces thermocarboxydovorans sp. nov. and Streptomyces thermocarboxydus sp. nov., two moderately thermophilic carboxydotrophic species from soil. Int J Syst Bacteriol 48, 59-68.

Kim, B., Al-Tai, A. M., Kim, S. B., Somasundaram, P. \& Goodfellow, M. (2000). Streptomyces thermocoprophilus sp. nov., a cellulase-free endo-xylanase-producing streptomycete. Int J Syst Evol Microbiol 50, 505-509.

Kim, S. B., Seong, C. N., Jeon, S. J., Bae, K. S. \& Goodfellow, M. (2004). Taxonomic study on neutrotolerant acidophilic actinomycetes isolated from soil and description of Streptomyces yeochonensis sp. nov. Int J Syst Evol Microbiol 54, 211-214.

Kimura, M. (1980). A simple method for estimating evolutionary rates of base substitutions through comparative studies of nucleotide sequences. J Mol Evol 16, 111-120.

Kluge, A. G. \& Farris, F. S. (1969). Quantitative phyletics and the evolution of anurans. Syst Zool 18, 1-32.

Kroppenstedt, R. M. (1985). Fatty acid and menaquinone analysis of actinomycetes and related organisms. In Chemical Methods in Bacterial Systematics, pp. 173-199. Edited by M. Goodfellow \& D. E. Minnikin. London: Academic Press.

Labeda, D. P. (1988). Kitasatosporia mediocidica sp. nov. Int J Syst Bacteriol 38, 287-290.

Lechevalier, H. A. \& Lechevalier, M. P. (1980). The chemotaxonomy of actinomycetes. In Actinomycete Taxonomy, Special Publication no. 6, pp. 277-284. Edited by A. Dietz \& D. W. Thayer. Arlington, VA: Society of Industrial Microbiology.

Lechevalier, M. P., De Bièvre, C. \& Lechevalier, H. A. (1977). Chemotaxonomy of aerobic actinomycetes: phospholipid composition. Biochem Syst Ecol 5, 249-260. 
Li, W., Lanoot, B., Zhang, Y., Vancanneyt, M., Swings, J. \& Liu, Z. (2002). Streptomyces scopiformis sp. nov., a novel streptomycete with fastigiate spore chains. Int J Syst Evol Microbiol 52, 1629-1633.

Marmur, J. \& Doty, P. (1962). Determination of base composition of deoxyribonucleic acid from its denaturation temperature. J Mol Biol 5, 109-118.

Minnikin, D. E., O'Donnell, A. G., Goodfellow, M., Alderson, G., Athalye, M., Schaal, A. \& Parlett, J. H. (1984). An integrated procedure for the extraction of isoprenoid quinones and polar lipids. J Microbiol Methods 2, 233-241.

Saintpierre, D., Amir, H., Pineau, R., Sembiring, L. \& Goodfellow, M. (2003). Streptomyces yatensis sp. nov., a novel bioactive streptomycete isolated from a New-Caledonian ultramafic soil. Antonie van Leeuwenhoek 83, 21-26.

Saitou, N. \& Nei, M. (1987). The neighbor-joining method: a new method for reconstructing phylogenetic trees. Mol Biol Evol 4, 406-425.
Sasser, M. (1990). Identification of Bacteria by Gas Chromatography of Cellular Fatty Acids. Technical Note 101. Newark, DE: Microbial ID.

Thompson, J. D., Gibson, T. J., Plewniak, F., Jeanmougin, F. \& Higgins, D. G. (1997). The CLUSTAL_X Windows interface: flexible strategies for multiple sequence alignment aided by quality analysis tools. Nucleic Acids Res 25, 4876-4882.

Wayne, L. G., Brenner, D. J., Colwell, R. R. \& 9 other authors (1987). Report of the ad hoc committee on reconciliation of approaches to bacterial systematics. Int J Syst Bacteriol 37, 463-464.

Williams, S. T., Goodfellow, M., Alderson, G., Wellington, E. M. H., Sneath, P. H. A. \& Sackin, M. J. (1983). Numerical classification of Streptomyces and related genera. J Gen Microbiol 129, 1743-1813.

Zhou, Z. H., Liu, Z. H., Qian, Y. D., Kim, S. B. \& Goodfellow, M. (1998). Saccharopolyspora spinosporotrichia sp. nov., a novel actinomycete from soil. Int J Syst Bacteriol 48, 53-58. 